
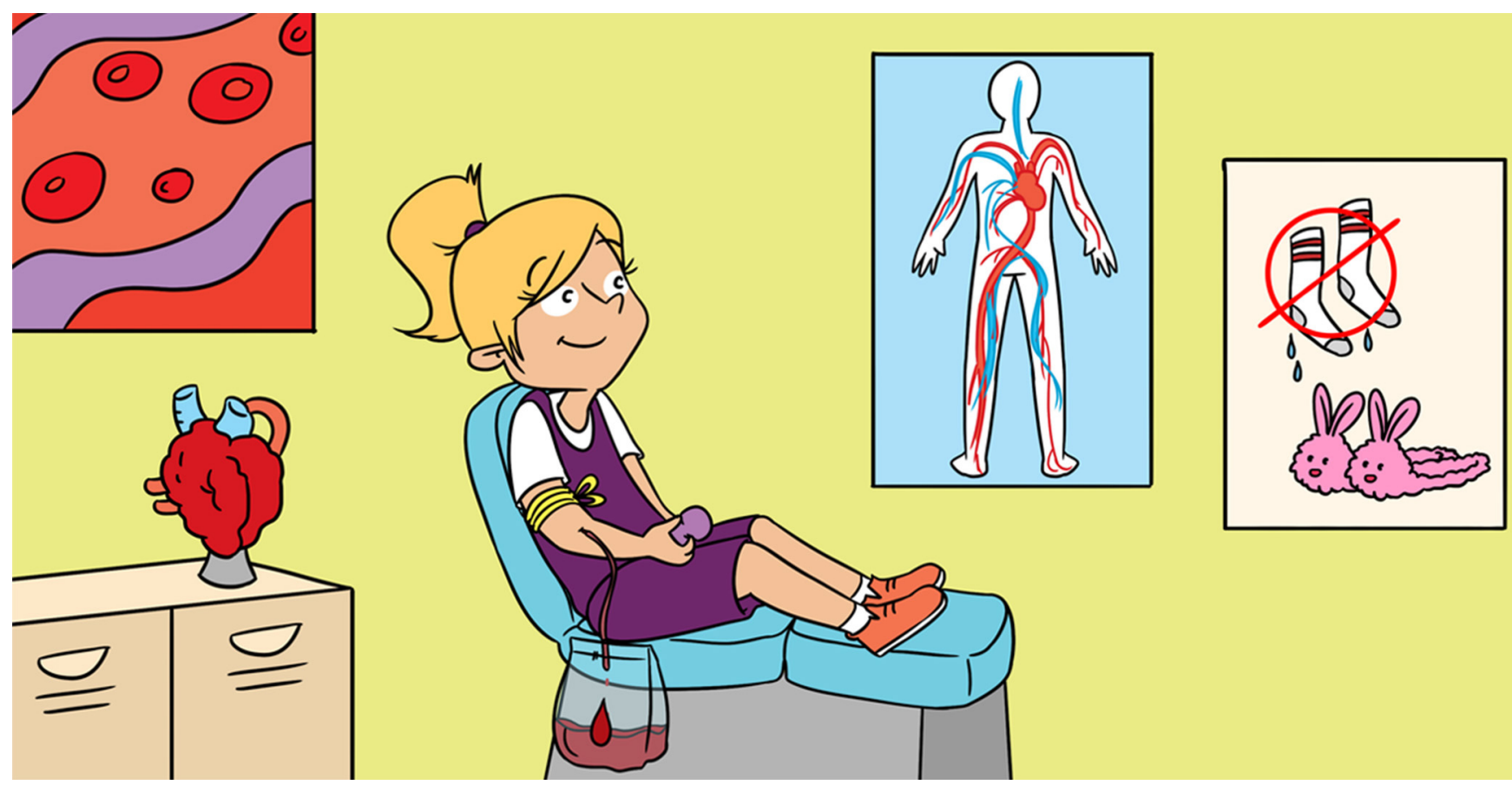

\title{
BLOOD VESSELS UNDER THE MICROSCOPE
}

\section{Maria J. C. Machado ${ }^{1+}$, Christopher A. Mitchell ${ }^{2+}$, Jemma Franklin ${ }^{1}$, Aaran Thorpe ${ }^{3}$ and Catrin Sian Rutland ${ }^{1 * t}$}

${ }^{1}$ Rutland Cardiovascular Laboratory, School of Veterinary Medicine and Science, Medical Faculty University of Nottingham, Nottingham, United Kingdom

${ }^{2}$ Centre for Molecular Biosciences, Ulster University, Coleraine, United Kingdom

${ }^{3}$ Roche Diagnostics Limited, Burgess Hill, United Kingdom

YOUNG REVIEWERS:

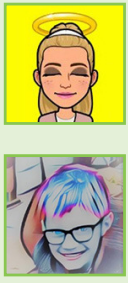

AMY

AGE: 11

EDWARD

AGE: 12

\section{ABBREVIATION}

BVs, blood vessels
This paper looks at blood vessels. All humans and animals have blood vessels, including your pet rabbit or dog, a whale or a giraffe! We need blood vessels to stay alive. This paper answers many questions, including what blood vessels are used for and why we need them. It looks at how and why blood vessels grow and what they look like. It also explores what happens when things go wrong with blood vessels and if blood vessels are ever bad for us. So, if you want to know how many miles of blood vessels there are in your body, learn about problems astronauts have in space, see real blood vessels through a microscope, or learn how to keep your blood vessels healthy, you are reading the right article.

\section{WHAT ARE BLOOD VESSELS AND WHY DO WE NEED THEM?}

Blood vessels (BVs) transport blood around the entire body. Blood is made up of red blood cells (carrying oxygen and nutrients to feed the body), water, hormones, proteins, salts, platelets, and white blood cells 
Figure 1

(A) Heart photographs from the front (left) and the back (right)-blood runs through the heart and is pumped to the entire body. You can see some blood vessels on the heart that deliver oxygen and nutrients to the heart itself. (B) A scanning electron microscope picture of the blood vessels in an organ called the pituitary gland. The pituitary gland makes many important hormones, including growth hormone, which controls how fast you grow. In this picture, the powerful microscope magnifies $1.5 \mathrm{~mm}$ of tissue and shows the blood vessels (white arrow) going in and out of this vital organ. A cell is located right next to a vessel!

\section{ARTERY}

A blood vessel that takes blood away from the heart to all parts of the body.

\section{OXYGENATED}

BLOOD

Blood that is carrying a lot of oxygen. Normally travels in arteries.

VEIN

A blood vessel which carries blood from the body to the heart.

\section{DEOXYGENATED}

BLOOD

Blood that contains low levels of oxygen. This normally travels in veins.

\section{CAPILLARY}

A small blood vessel just $5-10 \mu \mathrm{m}$ in diameter. A capillary wall is just one cell thick.

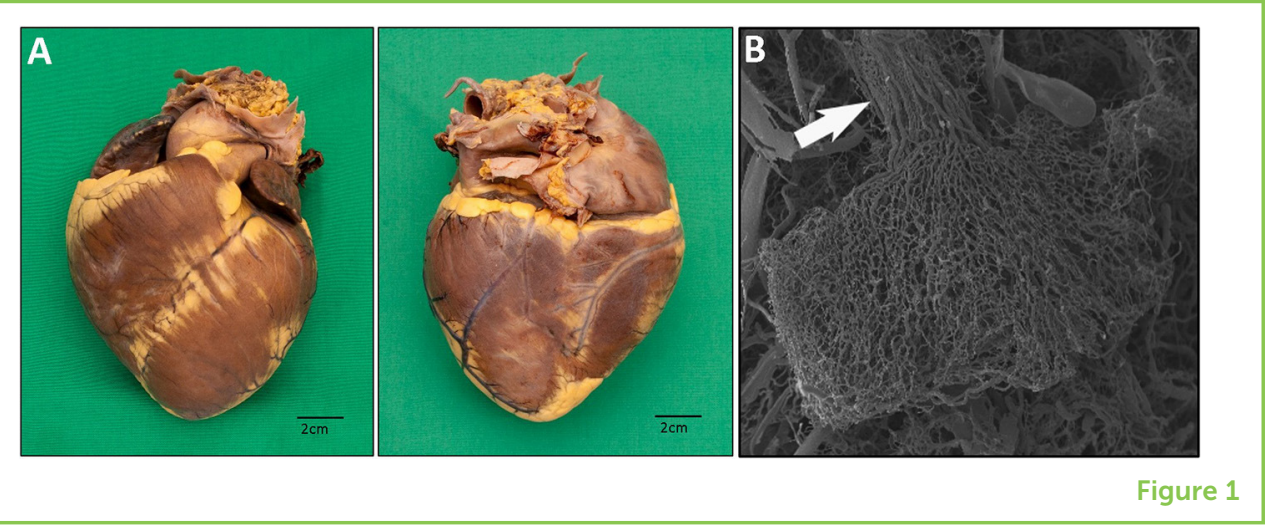

(to defend against germs and disease). Early doctors and scientists knew about BVs. An ancient Egyptian document called the Ebers Papyrus written 3,400 years ago talked about them. The blood system is much older than that though. It probably evolved over 600 million years ago [1].

The heart pumps blood into BVs, which spread throughout the body. Blood travels to every part of your body to drop off oxygen, nutrients, and white blood cells where they are needed and to pick up carbon dioxide and other waste so they can be disposed of. The heart even has its own BVs (Figure 1; see another Frontiers for Young Minds paper; Mending a Broken Heart-The Genetics of Heart Disease for more heart information [2]).

\section{WHAT DOES A BLOOD VESSEL LOOK LIKE?}

There are different types of BVs. Look at the back of your hand and you might see some BVs that look blue, even though the blood is red. Arteries (Figure 2) normally carry blood with oxygen (oxygenated blood) and veins normally carry blood with less oxygen (deoxygenated blood). Veins take blood back to the heart and lungs to get more oxygen.

Capillaries are the smallest types of BVs -there might be 10 billion capillaries in your body! It is estimated that children have over 60,000 miles of BVs in their bodies. If you traveled more than twice around the Earth, this would be the same distance! An adult has around 100,000 miles of BVs - four times around Earth! But how do they fit into your body? BVs can be up to $2-3 \mathrm{~cm}$ thick, but most are much smaller, for example 5 micrometer (that is 5 thousandth of a millimeter in size, tiny), so red blood cells have to fold up to go through them. Capillaries are so tiny that we can only see them with a microscope-they are thinner than a hair and smaller than a dot on a piece of paper.

\section{HOW AND WHY DO BLOOD VESSELS GROW?}

A tiny baby inside its mother starts growing BVs within 3 weeks. While the embryo is under $2 \mathrm{~mm}$ in size there are no blood vessels, so 
Figure 2

(A) Scanning electron microscope image showing a structure called the glomeruli in the kidney. Humans have about a million glomeruli in each kidney, and they serve to clean the blood [3]. (B) Microscope image showing a blood vessel, including

leukocytes/white blood cells (Leuk) and platelets (PI). Red blood cells (R) can have abnormal shapes, we call this crenation $(\mathrm{Cr})$. Smooth muscle cells (SMC) and internal elastic lamina (IEL) make arteries more flexible and collagen (ColB) makes blood vessels strong.

\section{MICROMETRE OR MICROMETER}

A unit of length. 1 millimetre/millimeter is 1 millionth of a meter, 1 thousandth of a millimetre/millimeter, $0.001 \mathrm{~mm}$.

\section{ANGIOGENESIS}

Making new blood vessels from ones that already exist.
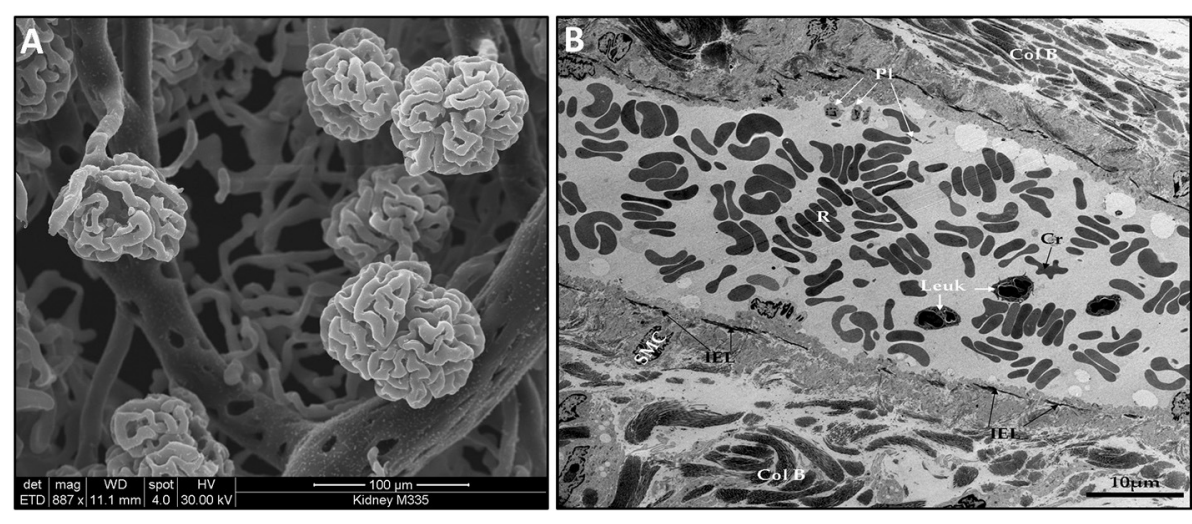

Figure 2

oxygen and nutrients are delivered to the cells via a process called diffusion. BVs start growing when some of the baby's cells, called hemangioblasts, develop into BVs and blood. Once BVs have been created, they can get longer, and more BVs can grow out of them. The scientific word for the process of BV growth is angiogenesis. By the time the baby is born, it has miles of BVs inside its little body. Oxygen and nutrients are delivered from the mother to the baby via the BVs in an organ called the placenta.

\section{WHAT HAPPENS WHEN BLOOD VESSELS GO WRONG?}

Every single day around 1,800 gallons $(6,813$ liters) of blood travels through your BVs, which is 657,000 gallons a year-enough to fill an Olympic-sized swimming pool! It is hardly surprising that problems can happen over time. Our bodies constantly fix broken or leaking BVs and make new ones. Sometimes BVs grow where they are not wanted, and people can become ill. Many of the diseases you have heard about, including cancer, arthritis, diabetes, and even Alzheimer's include BV problems.

BVs can break in any part of the body. A very hard sneeze or cough can break a BV in the eye. Blowing your nose a lot of times or very hard can break BVs in the nose and you can get a nosebleed. If you fall over and hurt your knee the skin might break, and you might start to bleed because broken BVs let some blood get out. It hurts but you probably clean the blood away to stop germs and dirt from getting in. Putting on a bandage also helps to keep the wound clean. You might also see a bruise appearing. These BV breaks are normally fine if we take care of ourselves. Luckily our bodies have special ways of healing. Platelet cells in the blood block up BV holes. If a cut is very bad, we might visit a doctor or nurse who can close up the hole so that the BVs can heal.

Although cutting your knee or having a nosebleed is normally fine, a big accident like a car crash might cut a lot of BVs, therefore we 
wear seat belts to try to prevent injuries. The average adult has 1.2 to 1.5 gallons $(4.5-5.5 \mathrm{~L})$ of blood. The amount of blood that children have can vary greatly because of their size, but there is around $75 \mathrm{ml}$ of blood per $\mathrm{kg}$ of body weight, so, for example, there is $1 \mathrm{~L}$ of blood in a child that weighs $13.3 \mathrm{~kg}$. A newborn baby has just 1 cup $(0.2 \mathrm{~L})$ of blood. If you lose around $20 \%$ of your blood, your body starts to struggle and needs to make or get more blood. Blood comes from people who are called blood donors. When donors give blood, their bodies eventually replace the lost blood. Blood donors, doctors, and nurses save lives by putting blood into people who need it.

Small BVs in your skin may temporarily shut down when it is cold, to help keep heat within your body, and they open up when it is warm, to cool you down. This opening and closing is normal but can cause pain if you are cold for too long. This is why we wear gloves in the cold weather. If you eat something cold your brain might feel cold, we call this a brain freeze. In a brain freeze, BVs in your mouth get smaller and you feel pain. Has anyone ever told you not to wear wet socks or shoes? Or suggested that you put slippers on to keep your feet warm? This is because when people get very cold or are wet for a long time, the BVs in their feet suffer and an illness called trench foot can result. Trench foot happens when the BVs deteriorate and destruct, leading to cell death in the surrounding areas.

Veins have little flaps called valves inside them to make blood flow in the correct direction. Sometimes these valves stop working or become damaged and the blood can flow in the wrong direction. This causes dark purple- colored varicose or spider veins to appear. On Earth, the valves help the blood go from the feet and legs back to the torso, because gravity pulls the blood down. In astronauts, the blood goes higher up, into the chest and head, so they get puffy faces and can get headaches!

Sometimes BVs become blocked up, stopping the blood flow. A clogged-up BV can cause pain, and if the BV is in the heart, the heart might stop working. A blocked BV can also lower the amount of oxygen getting to parts of the body and if that happens in the brain, the person might have a stroke. See this amazing Young Minds article; Taking Regular Breaks From Sitting Prevents Reductions in Brain Blood Flow, on brain blood flow [4]. In some cases, medicines or surgery might be needed to unblock the vessels.

Blood vessels can therefore be unhealthy in many ways. They may be broken, blocked, leaking, shrinking in size, have abnormal-looking red blood cells or dying blood cells (Figure 2), or a number of other abnormalities. 


\section{Figure 3}

Whether you are a dog, a rabbit, or a person, blood vessels must run throughout your body, carrying blood that is pumped around by the heart. Blood flow enables all of your cells to get oxygen and nutrients and to get rid of waste products.
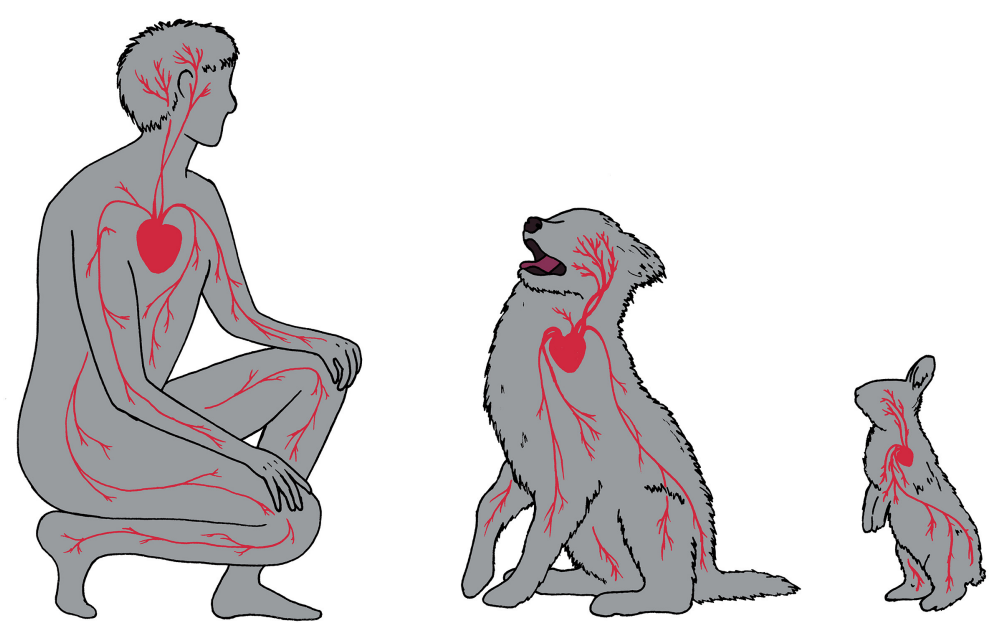

Figure 3

\section{ARE BLOOD VESSELS ALWAYS GOOD FOR US?}

Babies born early might have extra BVs in their eyes that stop them from seeing well, and sometimes these babies are blind $[5,6]$. These BVs should not exist as we grow up, but they do help the baby's eyes grow before they are born. People with an illness called diabetes can develop eye problems. The BVs in a diabetic's eyes become leaky, blood escapes and new vessels grow when they should not. The body tries to fix this, but the damaged BVs can cause problems, such as infection, blindness, pain, and the inability to deliver blood around the body properly.

Generally, tumors and cancers can only grow 1-2 mm in size before they need oxygen and nutrients, so new BVs must be created for tumors to grow. Scientists try to find ways to stop these BVs from growing, because without the BVs the tumor will not grow bigger. Stopping the BVs from growing in tumors is difficult though, because the rest of the body needs BVs, so we cannot just get rid of them all.

\section{LOVE YOUR BLOOD VESSELS}

Blood vessels are essential; they keep us and all animals alive (Figure 3). Embryos, newborn babies, children, adults, and elderly people all need blood vessels to enable nutrients and gases, such as oxygen to be distributed throughout the body. A healthy body will usually produce healthy blood vessels and will protect the BVs from becoming leaky or damaged. Drinking lots of water, eating good foods including fruits and vegetables, exercising, and eating only small amounts of sugar and fat can help keep your BVs healthy. Habits, such as smoking are bad for BVs. When you are out on your bicycle with friends, eating an apple, or walking with your family, you are being kind to your blood vessels. 


\section{ACKNOWLEDGMENTS}

We were very grateful to our employers for understanding the importance of science communication. CR would also like to thank the University of Nottingham and the British Science Association for funding her 2019 BSA Media Fellowship and the Anatomical Society for helping to fund this work a Public Engagement and Outreach grant to CR titled Anatomy for ALL-Making Anatomy Accessible. JF was undertaking a Ph.D. which was funded by the BBSRC and University of Nottingham (BB/M008770/1), her primary supervisor was Dr. Sabine Totemeyer. We all thank our young reviewers for reading this paper and making valuable contributions.

\section{REFERENCES}

1. Monahan-Earley, R., Dvorak, A. M., and Aird, W. C. 2013. Evolutionary origins of the blood vascular system and endothelium. J. Thromb. Haemost. 11:46-66. doi: $10.1111 /$ jth.12253

2. Clark, N., Alibhai, A., and Rutland, C. S. 2018. Mending a broken heart-the genetics of heart disease. Front. Young Minds 6:19.

doi: 10.3389/frym.2018.00019

3. Kelly, P., Denver, P., Satchell, S. C., Ackermann, M., Konerding, M. A., and Mitchell, C. A. 2017. Microvascular ultrastructural changes precede cognitive impairment in the murine APPswe/PS1dE9 model of Alzheimer's disease. Angiogenesis 20:567-80. doi: 10.1007/s10456-017-9568-3

4. Carter, S., Holder, S., Thijssen, D., and Hopkins, N. 2019. Taking regular breaks from sitting prevents reductions in brain blood flow. Front. Young Minds 7:77. doi: $10.3389 /$ frym.2019.00077

5. Rutland, C. S., Mitchell, C. A., Nasir, M., Konerding, M. A., and Drexler, H. C. 2007. Microphthalmia, persistent hyperplastic hyaloid vasculature and lens anomalies following overexpression of VEGF-A188 from the alphaA-crystallin promoter. Mol. Vis. 13:47-56.

6. Rutland, C. S., Jiang, K., Soff, G. A., and Mitchell, C. A. 2009. Maternal administration of anti-angiogenic agents, TNP-470 and Angiostatin4.5, induces fetal microphthalmia. Mol. Vis. 15:1260-9.

SUBMITTED: 16 July 2019; ACCEPTED: 11 December 2019;

PUBLISHED ONLINE: 13 January 2020.

EDITED BY: Tansy C. Hammarton, University of Glasgow, United Kingdom

CITATION: Machado MJC, Mitchell CA, Franklin J, Thorpe A and Rutland CS (2020) Blood Vessels Under the Microscope. Front. Young Minds 7:151. doi: 10.3389/frym. 2019.00151

CONFLICT OF INTEREST: The authors declare that the research was conducted in the absence of any commercial or financial relationships that could be construed as a potential conflict of interest. 

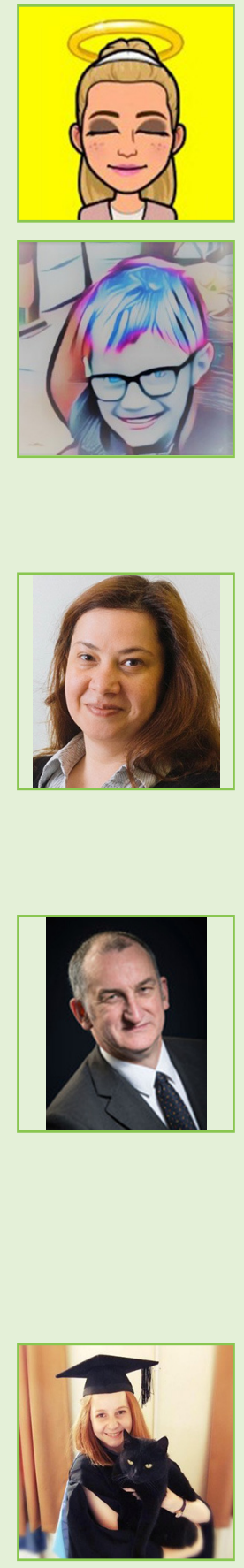

COPYRIGHT @ 2020 Machado, Mitchell, Franklin, Thorpe and Rutland. This is an open-access article distributed under the terms of the Creative Commons Attribution License (CC BY). The use, distribution or reproduction in other forums is permitted, provided the original author(s) and the copyright owner(s) are credited and that the original publication in this journal is cited, in accordance with accepted academic practice. No use, distribution or reproduction is permitted which does not comply with these terms.

\section{YOUNG REVIEWERS}

\section{AMY, AGE: 11}

Amy is age 11 and likes most sports but especially swimming. She also likes to bake cakes and spend time with her friends. She dislikes mushrooms and would love to be a teacher when she is older.

\section{EDWARD, AGE: 12}

Edward is a 12 years old boy who likes art and is fascinated by science. He likes to pass time by watching YouTube and playing on his Nintendo Switch. In the future he would like to become a computer engineer or technician.

\section{AUTHORS}

\section{MARIA J. C. MACHADO}

I have studied blood vessels in many places around the world. I looked at how wounds heal, what goes wrong when mutations cause failure in the blood vessels of baby animals, ways to improve damaged and diseased limbs and how blood vessels are different in cancer. I love photography and traveling. I keep my blood vessels healthy by doing yoga, walking by the beach and playing with my cat! machado.mjc@agmail.com; ${ }^{\dagger}$ orcid.org/0000-0002-2729-4809

\section{CHRISTOPHER A. MITCHELL}

I am a Professor of Tissue Regeneration at Ulster University. I teach research and molecular pathology to biomedical science and biology students here in Northern Ireland. My research looks at how blood vessels grow in health and disease as well as how we can improve tissue growth after damage (like in badly broken bones). In my spare time I exercise and get taken for walks by Ash the large white dog. I like to play the guitar and sing (even to students sometimes) and try to stay blood-vessel healthy by eating lots fish and so much salad that sometimes I feel like a rabbit. ca.mitchell@ulster.ac.uk; ${ }^{\circ}$ orcid.org/0000-0002-4422-7400

\section{JEMMA FRANKLIN}

I am a Ph.D. student in the School of Veterinary Medicine and Science, University of Nottingham. My research concentrates on how to keep animals healthy by trying to stop infections from causing illness. I keep my blood vessels happy by having regular cuddles with my two rabbits, Cas and Jodie, as well as singing in my campus choir and playing my clarinet in a Big Band, and viola at my church. I also love to sing, dance, and act in my drama society. stxjmf@exmail.nottingham.ac.uk 


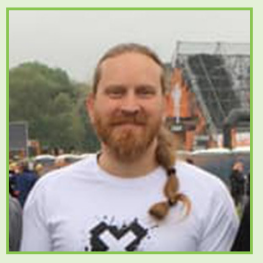

\section{AARAN THORPE}

I have been a research scientist in universities and industry for over 20 years. I have looked at the heart and blood vessels and lots of different disorders in humans and animals. I specialize in imaging, so I love microscopes. I keep my heart and blood vessels healthy by mountain biking, doing endurance races, and undertaking tough running and cycling challenges. aaran.thorpe@googlemail.com

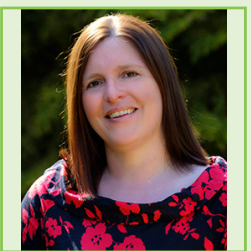

\section{CATRIN SIAN RUTLAND}

I am an Associate Professor of Anatomy and Developmental Genetics at The University of Nottingham. I teach anatomy and genetics to Veterinary Medicine students, and I lead a group of research scientists. My research looks at why people and animals suffer from heart and blood vessel disorders and try to find ways of helping them. When I am not at work I love to travel around the world, visit museums, and write science fiction. I go to the gym with friends and my boyfriend Andrew and I go running and eat lots of salad to keep my blood vessels healthy. *catrin.rutlandanottingham.ac.uk; †orcid.org/0000-0002-2009-4898 